\title{
Value Chain Structures that Define European Cellulosic Ethanol Production
}

\author{
Jay Sterling Gregg ${ }^{1, *}$, Simon Bolwig ${ }^{1}$, Teis Hansen ${ }^{2,3}$, Ola Solér ${ }^{1}$, Sara Ben Amer-Allam ${ }^{1}$, \\ Júlia Pladevall Viladecans ${ }^{1}$, Antje Klitkou ${ }^{3}$ and Arne Fevolden ${ }^{3}$ \\ 1 Department of Management Engineering, Technical University of Denmark (DTU), 2800 Kongens Lyngby, \\ Denmark; sibo@dtu.dk (S.B.); olasoler@gmail.com (O.S.); sbea@dtu.dk (S.B.A.-A.); \\ juliapladevall@gmail.com (J.P.V.) \\ 2 Department of Human Geography, Lund University, 22362 Lund, Sweden; Teis.Hansen@keg.lu.se \\ 3 NIFU Nordic Institute for Studies in Innovation, Research and Education, 0653 Oslo, Norway; \\ antje.klitkou@nifu.no (A.K.); arne.fevolden@nifu.no (A.F.) \\ * Correspondence: jsgr@dtu.dk
}

Academic Editor: Marc A. Rosen

Received: 30 November 2016; Accepted: 8 January 2017; Published: 14 January 2017

\begin{abstract}
Production of cellulosic ethanol (CE) has not yet reached the scale envisaged by the literature and industry. This study explores CE production in Europe to improve understanding of the motivations and barriers associated with this situation. To do this, we conduct a case study-based analysis of CE production plants across Europe from a global value chain (GVC) perspective. We find that most CE production plants in the EU focus largely on intellectual property and are therefore only at the pilot or demonstration scale. Crescentino, the largest CE production facility in Europe, is also more interested in technology licensing than producing ethanol. Demonstration-scale plants tend to have a larger variety of feedstocks, whereas forestry-based plants have more diversity of outputs. As scale increases, the diversity of feedstocks and outputs diminishes, and firms struggle with feedstock provisioning, global petroleum markets and higher financial risks. We argue that, to increase $\mathrm{CE}$ production, policies should consider value chains, promote the wider bio-economy of products and focus on economies of scope. Whereas the EU and its member states have ethanol quotas and blending targets, a more effective policy would be to seek to reduce the risks involved in financing capital projects, secure feedstock provisioning and support a diversity of end products.
\end{abstract}

Keywords: global value chain; biorefinery; cellulosic ethanol; bioenergy

\section{Introduction}

\subsection{Potential}

Global bioenergy use in 2013 was around 58 EJ, making bioenergy the world's largest source of renewable energy, comprising 10\% of global primary energy supply [1]. Currently, bioenergy supplies only four percent of global transport fuel. Nevertheless, the International Renewable Energy Agency (IRENA) [2] sees an auspicious future role for bioenergy, suggesting that by 2030 bioenergy consumption could exceed $100 \mathrm{EJ}$ and comprise over a quarter of the energy used in the transport sector. Estimates of the global technical bioenergy potential in 2050 range from below $100 \mathrm{EJ}$ to above $400 \mathrm{EJ}$, depending on assumptions about sustainability and socio-ecological constraints [3]. Global final energy consumption in the transport sector in 2012 was $110 \mathrm{EJ}$ and is projected to increase to over 160 EJ by 2040 [4]. Thus, a large share of this energy demand could potentially be met by bioenergy.

Biofuel production has increased dramatically since 2000, particularly in the US, the EU and Brazil. Global fuel ethanol production in 2015 was around 93 GL [5]. United States and Brazil together accounted for $85.3 \%$ of this production, while the EU produced $5.4 \%$ [5]. The majority of this production 
is from first-generation ethanol, that is, the fermentation of sugars and carbohydrates in food crops. Yet, sustainability concerns, including the impact of expanded production on food prices, are limiting the potential of starch and sugar-based ethanol [6]. Other analyses suggest that food prices will not rise significantly, especially if a greater share of ethanol comes from second-generation sources [7]. Second-generation ethanol includes fuels produced from spent black liquor (pulping liquor) from the forestry industry, municipal solid waste (MSW) and green waste, and lignocellulosic feedstocks such as energy crops (e.g., miscanthus and other energy grasses), agricultural residues, wood biomass, and municipal residue biomass (MRB). In this context, cellulosic ethanol (CE), ethanol produced from lignocellulosic feedstocks has been viewed more optimistically. This is because of its positive energy balance, lower life-cycle greenhouse gas (GHG) emissions and abundance of supply from feedstock, as well as its ability to be grown alongside food crops (see, for example $[8,9])$. Industry reports are very optimistic about the future potential of CE, estimating the 2030 potential at 350 GL-a 372-fold increase over 2014 production levels [10].

Despite large expectations, however, CE deployment continues to be slow in Europe. This paper aims to identify the reasons for this by analysing developments in the most important CE facilities in Europe: Inbicon (Denmark), Crescentino (Italy), Borregaard and Weyland (both Norway), Abengoa (Spain) and Örnsköldsvik (Sweden).

\subsection{European Policy Landscape}

The EU has been promoting biofuels through various policy mechanisms for almost a decade. Due to concerns over the environment and fuel insecurity, it has also established goals to be met by 2020. The EU Energy and Climate Change Package includes three main goals for 2020: (1) a $20 \%$ decrease in GHG emissions compared to 1990; (2) a 20\% improvement in energy efficiency for 2020; and (3) a 20\% share for renewable energy in the EU's total energy mix.

Two transport-focused policies support these overall goals. The first is the Fuel Quality Directive (2009/30), which requires each EU member state to reduce greenhouse gas fuel intensity by six percent in 2020 compared to 2010. The second is the Renewable Energy Directive (RED) [11], which requires that at least $10 \%$ of transport fuel in each member state should come from renewable energy by 2020 . Biofuels must comply with sustainability criteria in order to count towards the $10 \%$ goal in the RED. These criteria include reducing GHG emissions by $35 \%$ relative to fossil fuels (without accounting for any potential land-use changes) and avoiding feedstock grown on land with high biodiversity value or peat land or on land with high carbon content. In October 2012, the Commission also proposed to address the question of indirect land-use change (ILUC). One aim of this proposal is to launch the transition from first-generation biofuels to second-generation biofuels by adding weighting factors to second- and third-generation biofuels:

- Second-generation biofuels produced from lignocellulosic, waste, non-food cellulosic and residue materials will count double towards this target.

- Biofuels produced from municipal and industrial waste, straw, algae, palm oil, leaves, sawdust and branches will count four times towards the target.

Moreover, installations after 2017 must achieve gradually higher GHG savings, a criterion that in practice hinders new production facilities for first-generation ethanol from wheat and corn. The EU allows national governments to introduce measures such as taxes, subsidies and quotas to promote biofuels.

Biofuel policies in the United States and the European Union are becoming a driver for the development of second-generation biofuels worldwide. These are beginning to be produced commercially in some regions, although the majority of biorefineries are still at the pilot and demonstration scales. R\&D is ongoing in North America, Europe and some emerging economies such as Brazil, Thailand, China and India [12]. 


\subsection{National Policy Landscapes}

\subsubsection{Denmark}

The Danish government set the goal of phasing out fossil fuels by 2050, and bioenergy is a large part of this strategy [13]. While Danish policy currently subsidizes wheat straw $(700 \mathrm{DKK} / \mathrm{t}$ or $100 \mathrm{USD} / \mathrm{t}$ ) for combustion in power plants, no such subsidy applies to wheat straw converted into ethanol. In Denmark, the demand for straw for combined heat and power (CHP) production has declined in recent years, as power plants are shifting to wood chips [13]. Inbicon sells ethanol to Statoil, where it is used as a five-percent blend in gasoline. Because the EU requires ethanol to be blended with fossil fuels to receive credit under the Renewable Fuels Directive, the ethanol must be anhydrous (99\% alcohol). Bioethanol is still a nursery market in Denmark due to the lack of other domestic producers. Nevertheless, in 2014 an EUDP grant was awarded to the Maabjerg Energy Concept, a consortium of companies including DONG Energy, Novozymes, local utilities (Vestforsyning, Struer Forsyning) and the waste management company Nomi. The grant will support the construction of a new CE production plant in Maabjerg with an annual production capacity of 80 million litres.

\subsubsection{Italy}

In 2005, Italy adopted biofuel blending targets, one of the first EU member states to do so. The initial quota was for a one-percent blend in 2007, to be increased stepwise annually, based on the previous year's total fuel volume supplied [14]. The policy was amended in 2015, and biofuel blending targets were extended into the future in the same stepwise fashion: $2015,5 \%$; $2016,5.5 \%$, $2017,6.5 \%, 2018,7.5 \%, 2019,9 \%$, and from 2020, 10\% [14]. In addition, Italy was one of the first EU member states to introduce a mandatory quota for advanced biofuels (2018 1.2\%, 2019 1.2\%, $20201.6 \%$, 2022 2\%) [15]. The amended policy defines advanced biofuels as agricultural and industrial wastes (with the exception of cooking oils and animal fats), residues, cellulosic and ligno-cellulosic materials, and algae. Non-compliance subjects the fuel producers to fines. Since 2009, there has been some support for financial measures to reduce GHG emissions, but they are geared more towards power production, and it is unclear whether CE production would apply.

\subsubsection{Norway}

Norway is a challenging place in which to produce CE because feedstock is expensive (it has the highest wood prices in the world) and because of an unpredictable biofuel policy, which results in weak incentives for producing CE. In general, biomass is not competitive with fossil fuels because of its high costs and the low carbon tax on fossil fuels. Norwegian climate policy has been sceptical of advanced biofuels, and this has led to an unpredictable situation for firms engaged in advanced biofuel production. Nevertheless, Norway has set a goal to increase bioenergy use to $14 \mathrm{TWh}$ (approximately 50 PJ) by 2020 and to maintain it thereafter [16]. In 2006, the Norwegian government introduced a tax exemption for bio-ethanol, but only where it constitutes the main part of gasoline. In 2007, ethanol or flexi-fuel cars (E85 cars) were allowed a reduction in vehicle import duty equalling NOK 10,000 (1200 USD). Since 2010, there has been a mandatory target of $3.5 \%$ for all biofuels in Norway, an increase from $2.5 \%$ in 2009 [17]. The government plans to introduce a five percent mandatory target as soon as sufficient sustainability criteria have been formulated. After gaining experience in complying with the sustainability criteria, the target will be increased to 10\% by 2020 (Norway follows the EU target of achieving 10\% renewable fuels in transportation by 2020) [18]. In early 2013, Norway's Climate and Pollution Agency (KLIF) supported the introduction of a five percent mandatory target by January 2014, but the government did not view the sustainability criteria as sufficient and therefore decided to keep the target at $3.5 \%$. 


\subsubsection{Spain}

Spain has supported the use of biofuels through a policy focused on their use in transportation. Spain produces relatively small quantities of biofuel feedstock and may therefore have to become dependent on imports if biofuel production expands considerably. Spain is still far from reaching its national goals because of slow growth in the demand for biofuels. Spain began a system to incentivize renewable forms of energy in the late 1990s. This strategy has been continued by various succeeding administrations, generating continuity and stability, which has been beneficial to investor confidence. In 2002, the Spanish government set a tax exemption for biofuels with the aim of aiding the market penetration of renewable energies [19]. In 2003, the Spanish government set a $10 \%$ special deduction for investments in material and facilities used for the conversion of agricultural products into biofuels [20].

\subsubsection{Sweden}

Sweden has an energy tax and a carbon dioxide tax on fuels, corresponding to a total of 5.63 SEK/L (0.66 USD/L) of petrol sold in 2014. The ethanol proportion of fuels with a high share of ethanol (such as E85 with $85 \%$ first-generation ethanol and 15\% petrol) is exempted from both taxes [21]. As a result, petrol is penalised compared to ethanol with around $\$ 550 \mathrm{USD} / \mathrm{m}^{3}$ ethanol equivalent (at 2014 exchange rates). $\mathrm{CE}$ should therefore be highly competitive in Sweden, given the current relative costs for $\mathrm{CE}$ versus gasoline. However, uncertainty about future targets for second-generation biofuels in the EU—realized by tax exemptions, subsidies and quotas-is hampering the development of commercial CE production facilities.

\subsection{Economy of CE}

Cost is often cited as a barrier to CE production. While CE for non-fuel uses has been produced for decades in small quantities, the production of $\mathrm{CE}$ for transport fuels on a commercial scale has been limited by inefficient process technology (high production costs) and difficulties in sourcing and transporting feedstock in sufficient amounts. Two papers [12,22] considered the production cost of CE from corn stover in different studies and compared it with the production costs of corn ethanol and gasoline respectively. Their estimates showed that cellulosic ethanol from corn stover had a production cost in 2012 of $\$ 651 / \mathrm{m}^{3}$ versus $\$ 800 / \mathrm{m}^{3}$ for corn-starch ethanol (due to the high price of corn), yet the ethanol equivalent for gasoline was still considerably lower at $\$ 451 / \mathrm{m}^{3}$. A projection five years into the future indicated that CE from corn stover could come down to $\$ 495 / \mathrm{m}^{3}$ [22] demonstrate how a crude oil price of around $€ 150 / \mathrm{bbl}(\$ 1.25 / \mathrm{L})$ in 2020 would shift the production cost advantage to CE when learning effects are incorporated. Nevertheless, the general conclusion from their scenarios is that the production cost of $\mathrm{CE}$ still has to come down substantially to be in the same range as gasoline [23].

Literature on CE production highlights ways of reducing production costs: (1) enzyme cost reduction [24]; (2) reducing energy consumption for pre-treatment [25]; (3) securing feedstock provision [26] by increasing residue harvest rates [22] and enabling feedstock variability [27], and (4) reduction of risk in infrastructure investments [28]. It is generally assumed that unit production costs for $\mathrm{CE}$ will decrease as the scale of production increases and that larger biorefineries will have reduced costs through scaling effects [29].

\subsection{Hypothesis}

Given the large potential for CE, the climate and environmental benefits over first-generation ethanol and the policy support, it was expected that economies of scale would have been achieved and that more CE would be produced in Europe than is the case today. Yet currently, the majority of the CE production systems in Europe are still at the pilot or demonstration scales. In this paper, we hypothesize that the CE development process is structured by: (1) the nature of the feedstock and resource availability; (2) the characteristics of the industrial actors (institutional legacy, competences, existing capital stock/investments, incentives, objectives); and (3) coordination between actors in the 
$\mathrm{CE}$ value chain. We further hypothesize that the current structures are creating barriers to the greater diffusion of $C E$ in Europe. From this perspective, this paper seeks to identify those barriers and asks which policies can address them.

Applying an analytical perspective that explicitly takes value-chain relationships into account makes it possible to consider other aspects than simply cost minimization through economies of scale. Orthogonal to economies of scale, a cross-cutting aspect that is less often considered is economies of scope: the confluence of various resources, production technologies and bio-based co-product markets. The transition from producing CE as a high-value product in a small (food) market to producing as a low-value product in a large (energy) market is a challenge that requires operators to cut production costs drastically in refining, build larger processing plants (bio-refineries) and develop efficient systems for high-volume feedstock supply. Because such a transition would occur in a landscape with many different actors, resources and end uses, the scaling up of CE production involves more than just technical potential and favourable prices. Our claim is that increased CE production in Europe could be promoted more efficiently by considering the value chains that underlie CE production. From here, economies of scope could be supported within national and EU policies to promote greater production of CE.

\section{Analytical Framework}

To address this hypothesis and demonstrate our claim, we apply Global Value Chain (GVC) analysis. GVC analysis emerged in the early 1990s as a novel methodological tool for understanding the dynamics of economic globalization and international trade. It is based on the analysis of discrete value chains where input supply, production, trade and consumption or disposal are explicitly and, at least to some extent, coherently linked. In addition to the descriptive aspects of territoriality and the input-output structure, much GVC discussion has revolved around two analytical issues: how upgrading takes place along GVCs, and how GVCs are governed in the context of a larger institutional framework.

In GVC analysis, the concept of upgrading is used to identify the possibilities for producers to "move up the value chain", either by shifting to more rewarding functional positions, or by making products that have more value-added invested in them or that provide higher returns. The upgrading process is examined through the lens of how knowledge and information flow within value chains [30] and displays similarities with innovation system approaches.

Upgrading is about acquiring capabilities and accessing new market segments through participation in particular chains. Governance is the process by which so-called "lead firms" organize activities with the purpose of achieving a certain functional division of labour along a value chain, resulting in specific allocations of resources and distributions of gains. It involves setting of the terms of chain membership, the related incorporation/exclusion of other actors and the re-allocation of value-adding activities [31]. Recent literature points out that external actors such as governments, multilateral institutions and NGOs can significantly influence GVC governance [32], especially in emerging industries like those for renewables, thus creating multi-polar chains [33].

\section{Method}

To understand the dominant structures in the $\mathrm{CE}$ value chain and the links between them, we have created a conceptual model (Figure 1). In the framework outlined in Figure 1, we identify the dominant structures, and thus the limiting factors that define the value chains, in particular resource availability (determined by domestic feedstock supply), the process (shaped by legacy and institutional knowledge) and the end-use products (a function of economic demand). The policy landscape, both locally and globally, shapes the overlapping value chains through taxation and trade policies. 


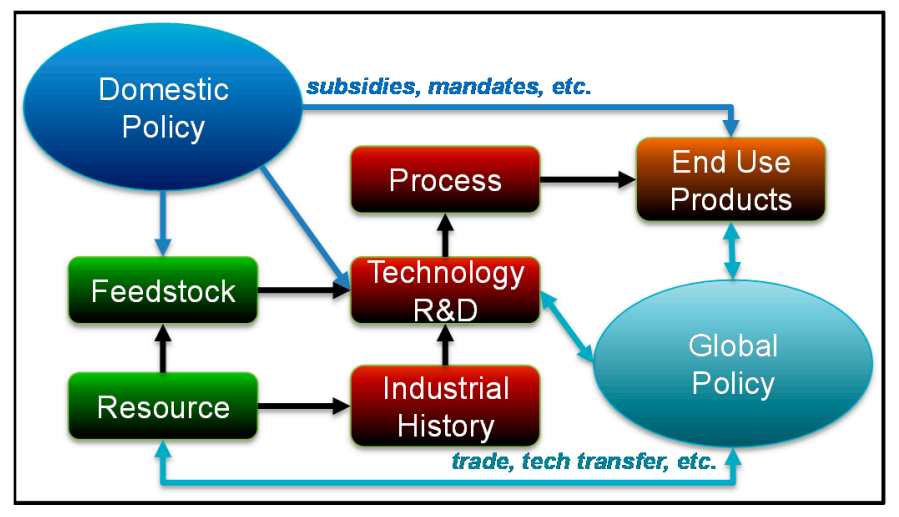

Figure 1. Conceptual framework.

In Figure 1, domestic policy is shown to affect feedstock production (e.g., forestry and agricultural subsidies and regulations) and technology investment (e.g., research grants and investment incentives). Domestic policy also has an influence on end use consumption through subsides, quotas, blending targets, etc. Global policy has an effect on the global trade of resources through trade policy (e.g., tariffs) and affects technology transfer through intellectual property protection. The main research activities around CE production have focused on the technological process of transforming a given feedstock into a marketable end product. This is shaped by resource availability and the institutional history of the firms. Using the overarching framework shown in Figure 1, we developed a protocol for case-study interviews of firms that produce CE within Europe.

Data were collected through six company case studies in Denmark (Inbicon), Italy (Crescentino), Norway (Borregaard and Weyland), Spain (Abengoa) and Sweden (Örnsköldsvik). The total production capacity of the six CE plants investigated by this study is $98.3 \mathrm{ML}$ per year, equivalent to $1.9 \%$ of total fuel ethanol production in the EU in 2015. We interviewed senior technical and managerial staff from the case-study firms in semi-structured, open-ended interviews. A total of twelve interviews were conducted between February 2013 and October 2015, nine in person and on site and three by telephone or email. The interviews typically took between one and two hours and were often conducted in connection with a visit to the bioethanol plant. Table 1 lists details of the interviews. Supplementary data were collected through reviews of scientific articles, company reports and websites, key financial figures and media coverage.

For each case study, we identify the feedstock, supply chain, technology and industrial process, production materials, distribution and end use (Figure 2). In addition, the case studies noted the institutional history, funding and national policy landscape. As the plants differ in terms of resources, technologies, policy landscapes and actors, the case studies can be used to understand, from different perspectives, how value chains form and function with respect to CE production. Using these case studies, we examine the innovation and industrial dynamics, highlighting the important links and characteristics of the pathway structures. In combination, this provides a detailed understanding of developments in the most important CE facilities in Europe, which should shed light on the reasons for the slow deployment of CE in Europe.

The survey also collected information on:

a. The position of the studied value chain actors in the global market in terms of technological advantage and presence in different markets

b. Feedstock supply

c. Firm characteristics (size, ownership, recent developments, etc.)

d. Innovations (major achievements), their characteristics (disruptive or incremental) and the factors that drive them (e.g., public R\&D funding)

e. Sources of finance for R\&D and the construction of larger plants 
f. Domestic market characteristics and the role of policy

g. Value added in different value chain segments (prices, costs, etc.)

Table 1. Details on case study data collection.

\begin{tabular}{cccc}
\hline Case & Interviewee (Staff Category) & Date of Interview & Type of Interview \\
\hline Inbicon & $\begin{array}{c}\text { Consultant and Developer } \\
\text { of IBUS Technology }\end{array}$ & 20 March 2013 & In person, in office \\
\hline Inbicon & Chief Consultant, Maabjerg Bioenergy & 22 March 2014 & In person, on site \\
\hline Inbicon & $\begin{array}{c}\text { Operational Manager, } \\
\text { Vinderup Kraftvarmeværk }\end{array}$ & 22 March 2014 & In person, on site \\
\hline Crescentino & $\begin{array}{c}\text { Strategic R\&D Partnerships and } \\
\text { Customs Director, Biochemtex }\end{array}$ & 13 October 2015 & $\begin{array}{c}\text { In person, on site. } \\
\text { Follow-up by telephone }\end{array}$ \\
\hline Borregaard & $\begin{array}{c}\text { Senior Vice President of R\&D and } \\
\text { Business Development, Borregaard }\end{array}$ & 15 May 2013 & Telephone \\
\hline Borregaard & $\begin{array}{c}\text { Technology Director Business } \\
\text { Development, Borregaard }\end{array}$ & 15 May 2013 & Site visit, informal \\
\hline Weyland & CEO of Weyland & April 2014 & Telephone \\
\hline Abengoa & $\begin{array}{c}\text { Process Development General } \\
\text { Manager, Abengoa Bioenergy }\end{array}$ & 10 April 2014 & Email and telephone \\
\hline Örnsköldsvik & Director, Domsjö & 13 May 2013 & In person, on site \\
\hline Örnsköldsvik & Vice President, SEKAB & 13 May 2013 & In person, on site \\
\hline Örnsköldsvik & Director, Processum & 13 May 2013 & In person, on site \\
\hline Örnsköldsvik & Senior Advisor, SP & 13 May 2013 & In person, on site \\
\hline
\end{tabular}

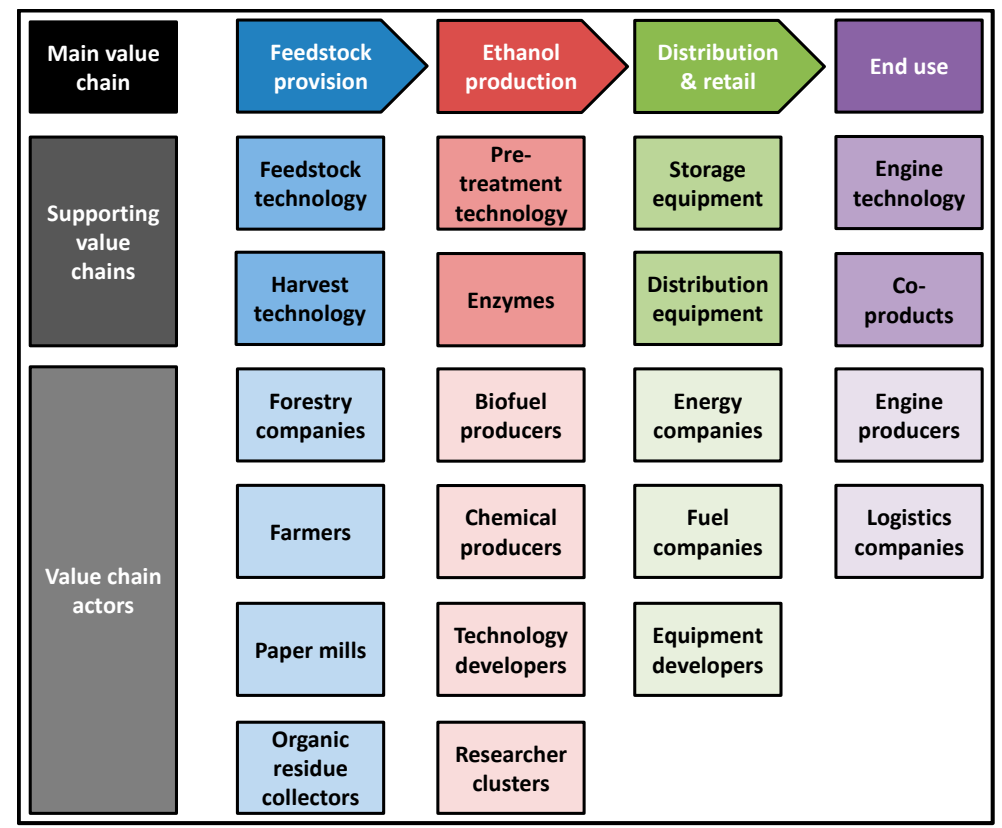

Figure 2. Analytical structure for value chain analysis of ethanol production.

\section{Results}

\subsection{Inbicon (Denmark)}

The first concepts and prototypes for a biorefinery plant were developed between the late 1990s and 2005, first by a Danish energy company, Elsam, then by Inbicon, a subsidiary of a merger between Elsam and six other energy companies to form DONG Energy (Danish Oil and Natural Gas). The first 
pilot plant was commissioned in 2003 and was scaled up to a capacity of $24 \mathrm{t} /$ day two years later. In 2009, efforts to market the process resulted in the first demonstration plant in Kalundborg, Denmark, with a capacity to convert $4 \mathrm{t} / \mathrm{h}$ of wheat straw, and integrated with the Asnæs Power Station. The plant has progressed to the production phase, while still continuing to test and optimize its systems [34].

Inbicon technology is a three-stage Integrated Biomass Utilization System (IBUS) process, consisting of hydrothermal pre-treatment, which releases lignin-cellulose in solid form; enzymatic hydrolysis, which separates cellulose from lignin and hemicellulose; and fermentation, which converts cellulose into ethanol. In 2010, Inbicon started the licensing process to sell its technology commercially Southeast Asia and globally.

Inbicon's unit in Kalundborg is currently the only CE refinery in Denmark, but DONG Energy plans to integrate a new CE plant with a hydrogen production plant and a waste treatment plant in the town of Maabjerg, Denmark. The biogas production of the existing Maabjerg BioEnergy plant will be increased, and the Maabjergværket biomass-fired cogeneration plant will be refurbished. The strategy of integrating biorefining with other types of energy production is designed to keep CE productions costs lower by sharing capital expenditures.

The development of Inbicon was linked to DONG Energy announcing waste biomass utilization as part of its $\mathrm{CO}_{2}$ reduction philosophy. The $5.4 \mathrm{ML} /$ year of ethanol it produces is sold to the oil company Statoil and distributed in a hundred filling stations across Denmark as Bio95 petrol (five-percent ethanol) [34]. Lignin pellets are sold to DONG Energy and used as a high-quality solid biofuel in power plants. The C5 molasses are sold as a biogas production booster in local biogas plants [34].

Although some firms are experimenting with genetically modified yeast capable of fermenting C5 molasses, this use is not necessarily economical at the present time, as the existing uses for fodder and biogas booster allow the portfolio of products to be broadened beyond CE. Moreover, the flexibility of $\mathrm{C} 5$ use can be increased by producing so-called single-cell proteins (SCPs). For example, in the Inbicon process, the yeast used in fermentation is also able to convert $\mathrm{C} 5$ molasses into various proteins that can be used further in many sectors. In order to allow flexibility, refineries could develop the capacity to shift between different output products, as well as different feedstocks (straw, whole grains, energy maize).

\subsection{Crescentino (Italy)}

The CE plant at Crescentino in Italy is the largest in Europe, with a production capacity of 40,000 t/year (approximately $50 \mathrm{ML}$ ) using 200,000 $\mathrm{t}$ straw. The plant came into operation in 2013 and is owned and funded by Beta Renewables, a joint venture between Biochemtex, a chemical engineering subsidiary; M\&G Group (Mossi Ghisolfi Group), a large family-owned chemical company that specializes in polymers; TPG, a US-based capital fund focused on green projects; and Novozymes, a Danish biotechnology firm specializing in enzyme R\&D and production. The M\&G Group is among the top three producers of polymers worldwide, and Novozymes is a world-leading industrial enzyme producer. The latter has developed enzymes that release simple sugars from cellulose (primarily wheat straw), which can then be fermented using yeast. The specialized yeast for CE is supplied by a third party (Leaf Technologies, owned by the French company Lesaffre).

Biochemtex received R\&D support under the EU FP7 programme, but most funds for R\&D come from the M\&G Group. Novozymes has likewise participated in publicly supported R\&D projects. Since 2005, the M\&G Group has invested USD 250 million in Biochemtex to develop biorefinery processes and technologies. One result of this investment is the Proesa ${ }^{\mathrm{TM}} \mathrm{Technology}$ for the pre-treatment of cellulosic biomass from agricultural residues and energy crops in biorefineries, which separate the cellulose and hemicellulose from the lignin. Among the claimed advantages of Proesa ${ }^{\mathrm{TM}}$ are low capital and operating costs, high efficiency, fully integrated process design and feedstock flexibility. A further claim is that the bioethanol produced using this technology can compete with fossil-based petrol at an oil price of 70 USD/barrel (approximately 0.6 USD/L), although the company is not involved in blending bioethanol with petrol or in petrol wholesaling or retailing (the CE is sold 
on-site to a major oil company under a long-term contract). The joint venture controls technologies for producing bioethanol and other biorefinery products. The Crescentino plant also produces electricity from lignin combustion, which it sells to the grid at a premium price (green certificate).

Biochemtex has carried out several agronomic studies of biomass supply (giant reed), handling and logistics. However, it is not directly involved in the production of agricultural residue feedstock. Original plans to source dedicated, locally produced giant reed and rice straw were abandoned because of logistical problems. Local wheat straw has been the main source of feedstock for the Crescentino plant, even though its cost is a major expense. One media report [35] claimed that the Crescentino plant had shifted from straw to wood chips because the high content of sand and dirt in the straw was causing technical problems. Furthermore, according to the same report, the Crescentino plant had consistently been producing far below capacity due to technical problems related mainly to unclean straw, and Novozymes had written the value of the project down to zero [35].

Though the Crescentino plant has the largest capacity for CE production in Europe, the main commercial strategy of Beta Renewables through Biochemtex is to develop, sell, license and service biorefining technology, rather than to produce CE. Crescentino is therefore a full-size demonstration plant. Proesa ${ }^{\mathrm{TM}}$-based projects are being considered in Brazil (using sugarcane bagasse), North Carolina (energy grass), California (energy cane and straw), China (wheat straw and corn stover) and Slovakia (wheat straw). A related strategy, being pursued by Beta Renewables through Biochemtex, is to focus $R \& D$ efforts increasingly on second-generation biorefinery products other than ethanol, for example, molecules that can be used as inputs to PET production.

\subsection{Borregaard (Norway)}

Borregaard was established in 1889 in Sarpsborg in Østfold County and has traditionally been engaged in processing pulp and paper. At the end of the 1930s the company started producing chemicals from the hemi-cellulose in spruce timber. Beginning in the 1950s, Borregaard used the lignin components of the feedstock for producing chemicals. After being taken over in 1986, it became part of the chemical division of the Orkla Group. Orkla is a Norwegian industrial conglomerate operating globally. While it has not been a driver of Borregaard's biorefinery strategy, Orkla nevertheless had a focus on value-added products and facilitated large comprehensive innovation and R\&D activities at Borregaard. Because of this, Borregaard, not Orkla, has made the strategic decisions regarding innovative and R\&D strategies. Borregaard's core business concept is that of a biorefinery that processes chemical products based on different types of lignocellulosic feedstock. In October 2012, Orkla floated Borregaard on the stock market. Borregaard has collaborated with a number of Norwegian R\&D organisations, such as the Norwegian University of Science and Technology, Sintef, the Norwegian University of Life Sciences and Østfold Research.

Borregaard has two plants at Sarpsborg, the commercial biorefinery and the BALI pilot. The former began operations in 1938 and is based on cooking spruce chips with acidic calcium bisulphite cooking liquor. Hemicellulose is hydrolysed to various sugars during the cooking process. After concentration of the sulphite spent liquor, the sugars are fermented, and ethanol is distilled off in several steps. This technology is rather energy-intensive, and over time fossil fuels have gradually been replaced by renewable energy sources; the production of industrial steam and electricity for the biorefinery is now based on residual products from the processes of the biorefinery, such as bark and wood chips, and additionally on heat from two MSW incineration plants. Borregaard has never been involved in producing first-generation biofuels, only CE. Furthermore, CE is in fact just a by-product of the total process, in which the production of valuable specialty cellulose and lignin is more central. Vanillin is another valuable end product of the biorefinery, being produced in smaller volumes than CE but at higher values. The commercial biorefinery produces annually $160,000 \mathrm{t}$ of speciality cellulose, $170,000 \mathrm{t}$ of speciality lignin, $20 \mathrm{ML}$ of CE, $1300 \mathrm{t}$ of bio-vanillin, $200 \mathrm{GWh}$ of electricity and $30 \mathrm{GWh}$ of biogas (anaerobic digestion) [36]. Borregaard is a market leader in global niche markets with a strong 
specialized product portfolio. In 2011, it had a turnover of four billion NOK (470 million USD) [37]. The CE it produces is sold both domestically and abroad.

The BALI pilot started in 2012 for demonstration purposes and does not produce ethanol for the market. The pilot produces ethanol, lignin, specialty chemicals, single cell protein and sugar derivatives. This technology is still in an early stage due to the status of the pilot project, but several sources of lignocellulosic feedstock have been tested, and the technical performance is thus far encouraging. The process in the BALI plant is disruptive because it is based on a patented chemical pre-treatment (a particular area of competence for Borregaard), saccharification with commercial enzymes and different types of fermentation: conventional fermentation of hexoses, aerobic fermentation or chemical conversion of pentoses, and chemical modification of lignin. This complex process enables the production of products from all components of the biomass, cellulose, hemicellulose and lignin and allows the low-cost hydrolysis of cellulose. Fewer enzymes are consumed than in other processes, and they can be recirculated. Borregaard plans to continue to be the world's leading supplier of lignin-based chemicals, with bio-ethanol as an important by-product. Its strategic goal is to build and operate plants in Europe or other parts of the world and not simply be a technology supplier.

The most important issue for Borregaard is to be geographically close to the biomass used in the process. At Borregaard, feedstock is provided by the local forestry industry, but the price of Norwegian wood is very high because of high transport costs. Therefore, if ethanol output is to increase, Norway needs to upgrade the forestry value chain and related transport system in order to provide large volumes of biomass because importing biomass is not seen as a sustainable option, according to the interviewees. Importing ethanol is not a good option either because the international supply of sustainably produced ethanol is limited. On the other hand, enzymes are bought from international firms, such as Novozymes in Denmark. In addition, enzymes can be stored or produced on site, and Borregaard is investigating enzyme recycling.

Several path dependencies are relevant to bio-ethanol and bio-refineries in Norway. These path dependencies are related to the following: first, the Norwegian economy and policy is oriented towards the exploitation of fossil fuels; second, electricity production is dominated by hydropower, and feed-in tariffs for electricity do not exist; third, the forestry sector is traditionally oriented towards the pulp and paper industry; and fourth, although there is plenty of unused forest biomass, its price is the highest in the world. As long as the Norwegian economy and state income are based on fossil fuels, the government will hesitate to provide better institutional framework conditions for CE. Likewise, the large capital investments necessary for CE infrastructure are unlikely to be made available. This is despite the fact that Norway has a huge amount of biomass available in unused forest resources in the form of both logs and forest residuals, the latter have the same price level as the logs. The global crisis in the pulp and paper industry also hit Norway, resulting in the closure of a number of the important industrial actors (i.e., Norske skog, Viken skog). This has contributed to reducing the size of Norway's forest-based value chain.

Therefore, in Norway, if one applies an enzymatic approach and exploits domestic wood resources, it is not a good option to concentrate just on producing bio-ethanol: a higher profit can be achieved from lignin chemicals and other value-added products. However, as the market for lignin is rather limited, the BALI process is unlikely to become a dominant design for biorefineries in the coming years. If market conditions should change and bio-ethanol becomes profitable because the costs of fossil carbon become too high, then the BALI process could become a dominant design for producing CE.

\subsection{Weyland (Norway)}

Weyland AS was established by Karl Weydahl and Knut Helland in 2001 in order to commercialize a technology for the production of CE. The technology was the result of research and development work conducted in cooperation with Bergen University College. In 2010, Weyland built a pilot plant to demonstrate its core technology. The plant had a capacity equivalent to approximately 200,000 L of ethanol output per year and demonstrated that the Weyland process for the recovery and recycling of 
the acid worked as intended. The purposes of the pilot plant were to verify and document the unique features of the process and to demonstrate the commercial viability of the technology. The pilot plant also served as a platform to scale the technology towards commercial-size plants and was well suited to running comprehensive experiments with different types of feedstock at a semi-industrial scale. Weyland's business plan was to provide hardware for strong acid hydrolysis for biorefineries and license its technology for use by other manufacturers, in addition to carrying out some consulting work.

Weyland's technology has been demonstrated with multiple cellulosic feedstocks, including sugarcane bagasse, corn stover, corn cobs, rice straw, hardwoods, softwoods, wood wastes and paper wastes. It ascribes its competitive advantage to the versatility of feedstocks that its production technology can handle.

Weyland has also developed a technology for producing CE using concentrated (strong) acid hydrolysis. Its production of $\mathrm{CE}$ is similar to other bio-chemical production processes and can be divided into the same five main phases: pre-treatment, hydrolysis, fermentation, distillation and separation. It is primarily in the hydrolysis phase that Weyland's approach differs from those of other bioethanol producers. In this phase, it makes use of concentrated acid and its patented process technology to recycle most of the acid $(98.5 \%)$ it uses in the hydrolysis process. Concentrated acid hydrolysis has the added advantage over diluted acid hydrolysis of higher sugar yields and lower operating temperatures. As in other types of bioethanol production, lignin is a by-product of the production process. The lignin can, among other things, be used as a fuel in the ethanol production plant boilers or be burnt in power plants. Weyland does not identify any particular use of its waste products since its pilot plant has been built primarily to demonstrate its technology.

Weyland is primarily a technology and hardware provider and has no plans to operate biorefineries itself. Its end users are therefore companies that want to construct and operate biorefineries. Weyland is in the process of developing and demonstrating its technologies. Its concentrated acid hydrolysis technology is mostly path-following, since most of the CE production process follows the same stages and uses the same technology as other CE producers. Limited access to risk capital and expensive wood resources are the main barriers to deploying Weyland's technology in Norway.

\subsection{Abengoa (Spain)}

Abengoa Bioenergy is the largest producer of bioethanol in Spain, owning three first-generation ethanol plants and a pilot-scale CE plant. This CE plant, located in Babilafuente (Salamanca), started in 2009 and is located inside the Biocarburantes de Castilla y León grain facility, also owned by Abengoa Bioenergy. The plant uses a standard technical process to produce $\mathrm{CE}$ from agricultural residues (primarily wheat straw, barley straw and corn stover), consisting of storage and preparation, pre-treatment, cellulose enzymatic hydrolysis and fermentation, and distillation [38]. There are also plans to expand the plant in order to produce ethanol from municipal solid waste, the aim being to have a diversity of inputs. The company currently produces approximately five megaliters of $\mathrm{CE}$ per year. Like Inbicon, the Abengoa CE plant produces two co-products: lignin and protein (C5 molasses). The lignin is used to generate electricity and steam for the consumption of the global process. The protein is removed before the pre-treatment process and is sold as cattle-feed added to the dried distiller grains (DDGs) from first-generation ethanol production.

Currently the CE produced at the Abengoa Salamanca plant is sold as a gasoline additive (ETBE) or as blend agents in the production of E10 and E85. As the plant is only at the demonstration scale, its main purpose is to generate knowledge and data for further large-scale CE plants. However, CE production at Abengoa is still expensive because of the difficulty of the process itself and the high cost of the facilities. Moreover, the existing harvesting, transport, distribution systems and storage are not yet sufficient to deliver large volumes of biomass. For this reason, more investment will be needed throughout the supply chain. The perceived risk of investments is one of the main financial barriers to expanding to commercial-scale CE. In the early 2010s, Abengoa took out cheap loans to 
expand the company's global operations, but Spain withdrew its support for renewable energy in 2013. The anticipated growth of the industry never happened due in part to low oil prices. By 2015, the Abengoa Company was $€ 15$ billion in debt and began bankruptcy proceedings. It has the potential to be the largest bankruptcy in Spanish history.

\section{6. Örnsköldsvik (Sweden)}

The biorefinery in Örnsköldsvik results from retrofitting a pulp and paper plant established in 1903. When the owners decided to close down the plant in 1996, a consortium of private investors took it over with the intention of transforming it into a biorefinery. Today, several firms are located on-site and collaborate in an industrial ecology setting. The core firm, Domsjö, is now owned by the Indian conglomerate Aditya Birla and focuses on the production of speciality cellulose, which is mainly used for viscose textiles. The annual product capacity of specialty cellulose is 255,000 tons, compared to 120,000 tons of lignin and 14,000 tons of bioethanol. The bioethanol is sold to the neighbouring firm SEKAB, which refines it further.

Production at the Örnsköldsvik mill takes place in the following steps. First, wood logs are debarked, chipped and fed into digesters with cooking chemicals. Subsequently, the cellulose is washed, bleached using hydrogen peroxide and then dried. During cooking, hemicellulose dissolves and is successively fermented with yeast and distilled into bioethanol [39].

A central barrier to increasing CE production at the plant is the decreasing attention being paid to this product by key actors. As the Indian owners acquired Domsjö in order to have access to a supply of pulp, their main focus is on regenerated cellulose and textile applications. While no significant change has occurred as yet, it was suggested in the interviews that there is now a greater focus on the textile applications of the specialty cellulose. It is likely that Domsjö's R\&D focus will increasingly turn towards these fields in the long run. Similarly, the firm SEKAB is increasingly focusing its development efforts on green chemicals rather than CE. Consequently, a pilot plant located at the biorefinery, which used to allow development activities related to wood-based $C E$ alone, is now focusing on other products such as green chemicals and specialty cellulose.

A key reason for the declining attention industry actors are giving to CE production is the widespread use of imported first-generation biofuels in Sweden. This use of imported bioethanol allows Sweden to fulfil its obligations towards the EU concerning the use of renewable energy in the transport sector, thus disincentivizing the implementation of policies specifically aimed at the diffusion of CE. Consequently, there is a lack of distinction between first-generation and CE in current policies [40].

Domsjö's production of bioethanol can be considered a by-product of the primary production of specialty cellulose. Thus, without the continuing production of specialty cellulose, there would be no bioethanol production at the plant. The specialty cellulose is primarily used in viscose clothing and hygiene products as an alternative to cotton and is also used by the pharmaceutical and food industries as a binding agent. The main customers are manufacturers of textiles and hygiene products, primarily in Asia, which has seen strong demand in recent years due to stagnation in cotton production. Domsjö estimates its global market share in the wood-based specialty cellulose at just over five percent. For products for which long-fibre cellulose is required, Domsjö's market share is ten percent.

The lignin produced is mostly used as concrete additives in the construction sector, where it works as a dispersant, reducing the use of water while maintaining the flow property. Domsjö exports the majority of its lignin production to manufacturers of concrete additives, but it also has customers that manufacture pellets for animal feeds and minerals. Domsjö estimates its global market share in lignin at around seven percent.

\subsection{Summary}

A summary of the case studies is given in Table 2 . 
Table 2. Case study descriptions.

\begin{tabular}{|c|c|c|c|c|c|c|c|}
\hline Firm/Plant & Country & Year Founded & Feedstock & Processing (Technology) & $\begin{array}{l}\text { CE Output } \\
\text { (ML/Year) }\end{array}$ & Co-Products & Sectors Involved \\
\hline Inbicon & Denmark & $\begin{array}{l}\text { Pilot plant: 2003; } \\
\text { Demonstration plant in } \\
\text { Kalundborg: } 2009\end{array}$ & Wheat straw & $\begin{array}{l}\text { hydrothermal pre-treatment, enzymatic } \\
\text { hydrolysis, fermentation }\end{array}$ & 5.4 & C5 Molasses, Lignin & $\begin{array}{l}\text { Agriculture, } \\
\text { transportation, power }\end{array}$ \\
\hline Crescentino & Italy & 2013 & Wheat straw & $\begin{array}{l}\text { hydrothermal pre-treatment, enzymatic } \\
\text { hydrolysis, fermentation }\end{array}$ & 50 & Electricity (from lignin) & $\begin{array}{c}\text { Agriculture, } \\
\text { transportation, power }\end{array}$ \\
\hline Borregaard & Norway & $\begin{array}{l}\text { Founded: 1889; } \\
\text { Commercial biorefinery: } \\
\text { 1938; BALI pilot: } 2012\end{array}$ & $\begin{array}{l}\text { Commercial plant): } \\
\text { wood chips (spruce), } \\
\text { BALI pilot plant: various } \\
\text { lignocellulosic feedstock }\end{array}$ & $\begin{array}{l}\text { Commercial plant: hydrothermal } \\
\text { pre-treatment with cooking liquor and acid } \\
\text { hydrolysis, fermentation and distillation. } \\
\text { BALI pilot: chemical pre-treatment, } \\
\text { saccharification with commercial enzymes, } \\
\text { conventional fermentation of hexoses, } \\
\text { aerobic fermentation or chemical } \\
\text { conversion of pentoses and chemical } \\
\text { modification of lignin. }\end{array}$ & 20 & $\begin{array}{l}\text { Speciality cellulose, } \\
\text { lignin-based products, } \\
\text { vanillin, fine chemicals, } \\
\text { pharmaceuticals }\end{array}$ & $\begin{array}{c}\text { Forestry, chemical industry, } \\
\text { construction industry, food } \\
\text { production, pharmaceutical } \\
\text { industry, etc. }\end{array}$ \\
\hline Weyland & Norway & 2001 & $\begin{array}{l}\text { Sugarcane bagasse, corn } \\
\text { stover, corn cobs, rice } \\
\text { straw, hardwoods, } \\
\text { softwoods, wood wastes } \\
\text { and paper wastes }\end{array}$ & $\begin{array}{l}\text { Concentrated (strong) acid hydrolysis, } \\
\text { with patented process technology to } \\
\text { recycle most of the acid }(98.5 \%)\end{array}$ & 0.2 & lignin & Forestry, chemical, transport \\
\hline Abengoa & Spain & & $\begin{array}{c}\text { Agricultural residue } \\
\text { (wheat, barley, corn), } \\
\text { municipal residue } \\
\text { biomass (MRB) }\end{array}$ & $\begin{array}{l}\text { Hydrothermal pre-treatment, enzymatic } \\
\text { hydrolysis, fermentation }\end{array}$ & 5 & C5 Molasses, lignin & $\begin{array}{l}\text { Agriculture, livestock, } \\
\text { transportation, municipal } \\
\text { waste }\end{array}$ \\
\hline Örnsköldsvik & Sweden & $\begin{array}{l}\text { Founded: 1903; } \\
\text { Biorefinery: } 2000\end{array}$ & Softwood and pulp & $\begin{array}{l}\text { Physical pre-treatment, bleaching, } \\
\text { enzymatic digestion }\end{array}$ & 17.7 & $\begin{array}{c}\text { Specialty cellulose } \\
\text { (hygiene and cosmetics), } \\
\text { lignin (for concrete), } \\
\text { solid fuel, biogas }\end{array}$ & $\begin{array}{l}\text { Forestry, pulp and paper, } \\
\text { chemical, commercial, } \\
\text { construction, electric } \\
\text { utilities, transport }\end{array}$ \\
\hline
\end{tabular}




\section{Discussion}

The various case studies can be roughly categorized into three groups:

(1) Forestry Based (Borregaard, Örnsköldsvik): The institutional legacy, feedstock availability and regional policies governing the resource structure the value chain and technological development. In general, CE production is motivated by re-conceptualizing and diversifying the markets for forestry products. This diversification produces a larger range of end-use actors and allows greater flexibility, thus making the bio-refinery part of a larger concept for the production of forestry-based products. This attracts more public (Borregaard) and international (Örnsköldsvik) R\&D support.

(2) Technology based (Inbicon, Weyland, Abengoa (Salamanca)): In this paradigm, the production of $\mathrm{CE}$ is not necessarily the end goal, but rather the development and licensing of the technology to produce it, making intellectual property the main output. The value chain is structured more by the global economic landscape and international initiatives and quotas for CE production (e.g., in the US). The scale and availability of feedstock supply is not a major concern for the pilot plants since the scale is small and production need not achieve an economy of scale. However, the flexibility of feedstock is more important, in order to expand the market for the intellectual property. Thus, these plants are developing the technology to convert different types of agricultural residues, energy crops and MRB. Regional government policies and incentives for feedstock provisioning and CE production are also not as relevant due to the limited scale of production. Furthermore, the R\&D tends to be private, being conducted either within the firm or through contracts (e.g., with Novozymes).

(3) Production scale (Crescentino, Abengoa (firm)): Like the technology-based categorization, here the motivation is to construct and sell CE production facilities rather than produce domestic CE. As the scale increases, however, firms generally become less flexible and diversified in feedstock and output, thus becoming more susceptible to fluctuations in global commodity prices for feedstock and petroleum. Regional government financial support is more important at this scale, as was particularly evident with Abengoa as a firm: the Abengoa Salamanca plant served as a demonstration-scale plant, but as it expanded to production scale in the US, government subsidies dried up. The firm struggled financially, having over-invested. In the Crescentino case, we find that feedstock provisioning becomes more challenging: the expenses of aggregation and transport, as well as reliability issues, work against the economies of scale in the CE production. Poor-quality (dirty) feedstock can significantly affect efficiency and hence profitability commercially. In Europe, commercial CE production plants are faltering.

Current national and EU policies that promote CE production have had only a limited impact in propelling growth in CE production. There seems to be little correlation between national policies for $\mathrm{CE}$ and the scale of production of CE within a country. For example, Borregaard is one of the largest plants in Europe in terms of CE production, yet Norway has some of the weakest government support of CE. While markets for feedstock and ethanol are national, markets for tech-licensing are global. In a business plan that focuses on technology licensing, current national fuel quotas are not particularly relevant. Likewise, for a business plan based on economies of scope, CE is not the main output, and the end-use market is much more diversified. Thus, we find a lack of coordination between the policy and the actors that form the value chains.

However, policies still have the potential to promote CE in a number of ways. Policies that target finance (e.g., low-interest loan guarantees) so as to reduce investor risk would be more likely to be effective at promoting growth in CE production than production targets or quotas. Public support for $R \& D$ is also important, as it changes the motivation away from simply private technology licensing. Third, policies that target feedstock provisioning are important to maintaining economies of scale as CE production grows. Finally, concerning the dominant technological design types, the flexibility of biorefining technologies is a key issue for biorefineries. Increasing flexibility would allow different 
feedstocks to be used and different end-products to be produced, thus improving the incentives for innovation. Policies should therefore be broadened to take into account the bio-economy as a whole, rather than just focusing on fuels.

\section{Conclusions}

In the literature on the potential of bioenergy, the methodologies employed tend to focus on land availability and crop yields (and thus feedstock availability), after subtracting out the amount required for food and feed production. Conversion technologies and their consequent market prices for CE are then employed to assess the economic potential. Much current policy reflects this line of reasoning, seeking to promote economies of scale by setting mandates and targets (perhaps reinforced by tax incentives) and supporting technical research to reduce CE production costs. However, this fails to take into account the complex value chain of $\mathrm{CE}$ production that includes distribution, retail and end use, not only of $\mathrm{CE}$, but of all its simultaneously produced co-products. Coordination of multiple value chains is required (economy of scope) in order to achieve economies of scale for CE.

Policies to promote CE production tend to focus on targets and mandates for CE production (renewable energy targets, penalties), that is, they tend to focus on economies of scale. Yet the barriers to economies of scale for $\mathrm{CE}$ are more than just technological: from a global value chain perspective, achieving economies of scale (and thus reducing prices) requires the coordination of many actors. Therefore, expanding policies to focus on economies of scope would be more effective in overcoming the barriers to producing $\mathrm{CE}$ at competitive prices. Policy could then be crafted so as to address specific barriers in expanding CE production such as investment risk and feedstock provisioning. Such a policy landscape would foster greater coordination between actors and allow a greater production of CE.

By considering economies of scope (in both feedstock and output) and maintaining this focus as scale increases, prices would be reduced more efficiently because diversification would reduce risk. This would promote better market development for CE. In general, a policy that promotes better integration of the whole value chain and an orientation towards more value-added products in this sector could be a step forward in the direction of a more bio-based economy.

Acknowledgments: Research for this study occurred under the TOP-NEST (Technology Opportunities in Nordic Energy System Transitions) project, which was funded by Nordic Energy Research (SES 2050/project No. 42); and the SusValueWaste (Sustainable path creation for innovative value chains for organic waste products) which was funded by the Research Council of Norway, Bionær Programme (project No. 244249). We are grateful for Simone La Greca's assistance with logistics for the Italian case study (Crescentino). The text of the manuscript was improved based upon the thoughtful comments of two anonymous reviewers.

Author Contributions: Arne Fevolden and Antje Klitkou were responsible for the Norwegian case studies (Borregaard and Weyland) and research on the Norwegian policy landscape. Júlia Pladevall Viladecans was responsible for the Spanish case study (Abengoa) and research on the Spanish policy Landscape. Sara Ben Amer-Allam conducted field research on the Danish case study (Inbicon) and Danish policy landscape. Ola Solér conducted background research on the EU policy landscape and theoretical background, and helped developed the analytical structure. Teis Hansen was responsible the Swedish case study (Örnsköldsvik) and Swedish policy landscape, and helped develop the hypothesis for the study. Simon Bolwig conducted field research on the Danish (Inbicon) and Italian (Crescentino) case studies, and developed the methodology. Jay Sterling Gregg conducted field research on the Italian case study (Crescentino), developed the hypothesis, and wrote the paper. All authors contributed to editing and commenting on early internal drafts.

Conflicts of Interest: The authors declare no conflict of interest.

\section{References}

1. International Energy Agency (IEA). World Energy Outlook; OECD-IEA: Paris, France, 2014.

2. UAE. 2014. Available online: http://irena.org/remap/REmap_Report_June_2014.pdf (accessed on 12 January 2017).

3. Berndes, G.; Hoogwijk, M.; van den Broek, R. The contribution of biomass in the future global energy supply: A review of 17 studies. Biomass Bioenergy 2003, 25, 1-28. [CrossRef] 
4. Energy Information Administration (EIA). Transportation Sector Energy Consumption in International Energy Outlook. 2016. Available online: http://www.eia.gov/outlooks/ieo/transportation.cfm (accessed on 12 January 2017).

5. Renewable Fuels Association (RFA). Industry Statistics. 2016. Available online: http://ethanolrfa.org/ resources/industry/statistics/ (accessed on 12 January 2017).

6. Johansson, D.J.; Azar, C. A scenario based analysis of land competition between food and bioenergy production in the US. Clim. Chang. 2007, 82, 267-291. [CrossRef]

7. Ajanovic, A. Biofuels versus food production: Does biofuels production increase food prices? Energy 2011, 36, 2070-2076. [CrossRef]

8. Lynd, L.R.; Cushman, J.H.; Nichols, R.J.; Wyman, C.E. Fuel Ethanol from Cellulosic Biomass. Science 1991, 251, 1318-1323. [CrossRef] [PubMed]

9. Creutzig, F.; Ravindranath, N.H.; Berndes, G.; Bolwig, S.; Bright, R.; Cherubini, F.; Chum, H.; Corbera, E.; Delucchi, M.; Faaij, A.; et al. Bioenergy and climate change mitigation: An assessment. Glob. Chang. Biol. Bioenergy 2015, 7, 916-944. [CrossRef]

10. Bloomberg. Bloomberg New Energy Outlook. 2012. Available online: https://www.bloomberg.com/ company/new-energy-outlook/ (accessed on 12 January 2017).

11. European Parliament, Directive 2009/28/EC. Available online: http:/ / eur-lex.europa.eu/legal-content/ EN/ALL/?uri=CELEX\%3A32009L0028 (accessed on 12 January 2017).

12. Eisentraut, A. Sustainable Production of Second-Generation Biofuels- Potential and Perspectives in Major Economies and Developing Countries; OECD-IEA Information Paper; OECD-IEA: Paris, France, 2010; Available online: http://www.oecd-ilibrary.org/energy/sustainable-production-of-second-generationbiofuels_5kmh3njpt6r0-en (accessed on 12 January 2017).

13. Gregg, J.S.; Bolwig, S.; Solér, O.; Vejlgaard, L.; Gundersen, S.H.; Grohnheit, P.E.; Herrmann, I.T.; Karlsson, K.B. Experiences with biomass in Denmark; Department of Management Engineering, Technical University of Denmark: Roskilde, Denmark, 2014; Available online: http:/ /orbit.dtu.dk/files/97912187/Experiences_ with_biomass_in_Denmark.pdf (accessed on 12 January 2017).

14. International Energy Agency (IEA). Policies and Measures-Italy-Biofuels aid Scheme: Quotas. Available online: https://www.iea.org/policiesandmeasures/pams/italy/name-24276-en.php (accessed on 12 January 2017).

15. Ministero del Commercio con L'estero. Decreto 10 Ottobre 2014. Available online: http://www. gazzettaufficiale.it/atto/serie_generale/caricaDettaglioAtto/originario?atto.dataPubblicazioneGazzetta= 2014-10-27\&atto.codiceRedazionale=14A08212\&elenco30giorni=false (accessed on 12 January 2017). (In Italian)

16. Norge Regjeringen: Klima-og Miljødepartementet, Norsk Klimapolitikk St.meld. nr. 34 (2006-2007). Available online: https://www.regjeringen.no/no/dokumenter/Stmeld-nr-34-2006-2007-/id473411/ (accessed on 12 January 2017). (In Norwegian)

17. Fevolden, A.; Klitkou, A. A fuel too far? Technology, innovation, and transition in failed biofuel development in Norway. Energy Res. Soc. Sci. 2017, 23, 125-135. [CrossRef]

18. Norge Regjeringen: Klima-og Miljødepartementet, Norsk Klimapolitikk St.meld. nr. 21 (2011-2012). Available online: https://www.regjeringen.no/no/dokumenter/meld-st-21-2011-2012/ id679374/ (accessed on 12 January 2017). (In Norwegian)

19. Órgano Jefatura del Estado, Ley 53/2002, de 30 de Diciembre, de Medidas Fiscales, Administrativas y del Orden Social. Available online: http://noticias.juridicas.com/base_datos/Admin/153-2002.html (accessed on 12 January 2017). (In Spanish)

20. Órgano Jefatura del Estado, Ley 36/2003, de 11 de Noviembre, de Medidas de Reforma Económica. Available online: http://noticias.juridicas.com/base_datos/Admin/136-2003.html (accessed on 12 January 2017). (In Spanish)

21. Sverige Finansdepartementet, Lag (1994:1776) om Skatt på Energi. Available online: http:/ /www.notisum. $\mathrm{se} / \mathrm{rnp} / \mathrm{sls} / \mathrm{lag} / 19941776 . \mathrm{htm}$ (accessed on 12 January 2017). (In Swedish)

22. Chovau, S.; Degrauwe, D.; van der Bruggen, B. Critical analysis of techno-economic estimates for the production cost of lignocellulosic bio-ethanol. Renew. Sustain. Energy Rev. 2013, 26, 307-321. [CrossRef]

23. Festel, G.; Würmseher, M.; Rammer, C.; Boles, E.; Bellof, M. Modelling production cost scenarios for biofuels and fossil fuels in Europe. J. Clean. Prod. 2014, 66, 242-253. [CrossRef] 
24. Ekman, A.; Wallberg, O.; Joelsson, E.; Börjesson, P. Possibilities for sustainable biorefineries based on agricultural residues: A case study of potential straw-based ethanol production in Sweden. Appl. Energy 2013, 102, 299-308. [CrossRef]

25. Zhu, J.Y.; Pan, X.J. Woody biomass pretreatment for cellulosic ethanol production: Technology and energy consumption evaluation. Bioresour. Technol. 2010, 101, 4992-5002. [CrossRef] [PubMed]

26. Dautzenberg, K.; Hanf, J. Biofuel chain development in Germany: Organisation, opportunities, and challenges. Energy Policy 2008, 36, 485-489. [CrossRef]

27. Limayem, A.; Ricke, S.C. Lignocellulosic biomass for bioethanol production: Current perspectives, potential issues and future prospects. Prog. Energy Combust. Sci. 2012, 38, 449-467. [CrossRef]

28. McCormick, K.; Kåberger, T. Key barriers for bioenergy in Europe: Economic conditions, know-how and institutional capacity, and supply chain co-ordination. Biomass Bioenergy 2007, 31, 443-452. [CrossRef]

29. Hamelinck, C.N.; van Hooijdonk, G.; Faaij, A.P. Ethanol from lignocellulosic biomass: Techno-economic performance in short-, middle- and long-term. Biomass Bioenergy 2005, 28, 384-410. [CrossRef]

30. Gereffi, G. International trade and industrial upgrading in the apparel commodity chain. J. Int. Econ. 1999, 48, 37-70. [CrossRef]

31. Gereffi, G. The Organization of Buyer-Driven Global Commodity Chains: How US Retailers Shape Overseas Production Networks. In Commodity Chains and Global Capitalism; Gereffi, G., Korzeniewicz, M., Eds.; Praeger: Westport, CT, USA, 1994; pp. 96-122.

32. Bolwig, S.; Ponte, S.; Du Toit, A.; Riisgaard, L.; Halberg, N. Integrating poverty and environmental concerns into value-chain analysis: A conceptual framework. Dev. Policy Rev. 2010, 28, 173-194. [CrossRef]

33. Ponte, S. The evolutionary dynamics of biofuel value chains: From unipolar and government driven to multipolar governance. Environ. Plan. A 2014, 46, 353-372. [CrossRef]

34. Larsen, J.; Østergaard Haven, M.; Thirup, L. Inbicon makes lignocellulosic ethanol a commercial reality. Biomass Bioenergy 2012, 46, 36-45. [CrossRef]

35. Alsman, S.W. 'Novozymes' Prestigefabrik Til 650 Mio Halter. Børsen. Available online: http://borsen.dk/ nyheder/avisen/artikel/11/142082/artikel.html (accessed on 24 May 2016). (In Danish)

36. Johansen, G.L. Creating value from wood: The Borregaard Biorefinery. In Proceedings of the Biofuels and Bioenergy: A Changing Climate, IEA Bioenergy Multi Task Conference, Vancouver, BC, Canada, 23-26 August 2009.

37. Johansen, G.L. Den Grønne Oljen—Drivstoff og Biokjemikalier Fra Verdens Mest Avanserte Bioraffineri. 2011. Available online: http://www.umb.no/statisk/konferanser/fagdag_fornybarenergi/Foredrag fagdagfornybarenergi/borregaardgislelj.pdf (accessed on 12 January 2017). (In Norwegian)

38. Abengoa Bioenergy. 2012 Annual Report-Activities Report. Available online: http://www. abengoabioenergy.com/export/sites/abg_bioenergy/resources/pdf/acerca_de/en/Annual_Report_ 2012_1.pdf (accessed on 12 January 2017).

39. Fabriker, D. We Make More from the Tree. 2012. Available online: http://www.domsjo.adityabirla.com/en/ Documents/Presentations/we_make_more_from_the_tree.pdf (accessed on 12 January 2017).

40. Klitkou, A.; Bolwig, S.; Hansen, T.; Wessberg, N. The role of lock-in mechanisms in transition processes: The case of energy for road transport. Environ. Innov. Soc. Transit. 2015, 16, 22-37. [CrossRef]

(C) 2017 by the authors; licensee MDPI, Basel, Switzerland. This article is an open access article distributed under the terms and conditions of the Creative Commons Attribution (CC-BY) license (http://creativecommons.org/licenses/by/4.0/). 